\title{
Quality of Life in Regeneration Areas: Empirical Findings from the Akpınar Neighbourhood, Ankara, Turkey
}

\author{
Dönüşüm Alanlarında Yaşam Kalitesi: Ankara, Akpınar Mahallesi’nden \\ Ampirik Bulgular
}

\section{Ezgi Orhan, Zerrin Ezgi Kahraman}

Department of City and Regional Planning, Cankaya University, Ankara, Turkey

\begin{abstract}
This article is a discussion of the concept of quality of life in a regeneration area based on the personal evaluation of residents. Developed by social scientists to evaluate people's well-being, satisfaction, and happiness, the concept of quality of life raises the issue of adapting the conditions of living spaces to meet people's needs, expectations, and demands. The aim of this study was to establish an integrated and comprehensive framework for evaluating the quality of life in a regeneration case in Turkey through empirical research conducted at the neighborhood level. Data were collected from 359 households in the regenerated neighborhood of Akpınar, in the city of Ankara, using a questionnaire to inquire about the quality of life. The methodological framework of the study included a theory-based choice of indicators identified in a comprehensive literature review, including economic, ecological, physical, and social aspects of an urban environment, and an analysis of the relationship of the indicators to quality of life. Despite the diverse literature on urban environmental quality, there is no uniform, generally accepted conceptual framework to measure quality of life. Therefore, in this research, a mix of qualitative and quantitative analysis was adopted to assess the quality of life of the residents with respect to their housing and urban environment. The findings suggested that modern quality of life requires understanding the social, political, spatial conditions, and needs of residents. Based on the findings of the study, policy recommendations were developed to enhance quality of life at the neighborhood level from a space-sensitive perspective.
\end{abstract}

Keywords: Housing satisfaction; public well-being; urban liveability; quality of life; regeneration.

\section{ÖZ}

Bu çalışma, dönüşüm alanlarında yaşayanların kişisel değerlendirmelerinden yola çıkarak yaşam kalitesi kavramını tartışmaktadır. Sosyal bilimciler tarafından insanların refah, memnuniyet ve mutluluğunu değerlendirmek üzere geliştirilen yaşam kalitesi kavramı, yaşama alanlarının koşullarının insanların ihtiyaç, beklenti ve taleplerini karşılayacak biçimde uyarlanması konusunu gündeme getirmektedir. Bu çalışmanın amacı mahalle ölçeğinde yürütülen ampirik bir araştırma ile Türkiye'de dönüşüm alanlarındaki yaşam kalitesini değerlendirecek kapsamlı ve bütüncül bir çerçeve geliştirmektir. Çalışmada kullanılan veri seti Ankara'nın dönüşüm geçirmiş bir mahallesi olan Akpınar Mahallesin'de ikamet eden 359 hanehalkıyla gerçekleştirilmiş olan bir yaşam kalitesi anketi uygulanması yoluyla elde edilmiştir. Araştırmanın yöntemsel çerçevesi kapsamlı bir literatür taraması sonucunda elde edilen çok boyutlu kentsel yaşam göstergelerinin (kentsel çevrenin ekonomik, ekolojik, fiziki ve sosyal boyutlarını kapsayan) belirlenmesini ve bu göstergelerin yaşam kalitesi ile ilişkilerinin analiz edilmesi aşamalarını içermektedir. Kentsel çevre kalitesine yönelik çok sayıda çalışmanın varlığına karşın, yaşam kalitesinin ölçülmesinde kullanılan kabul edilmiş ortak bir kavramsal çerçeve bulunmamaktadır. Bu nedenle, bu araştırma konut ve kentsel çevreyi birlikte ele alarak hanehalklarının yaşam kalitesini değerlendirmek üzere nitel ve nicel araştırma yöntemlerini kullanmıştır. Çalışmanın bulguları modern yaşamın kalitesinin gereği olarak yaşayanların sosyal, politik ve mekansal koşullarını ve ihtiyaçlarını anlamak ihtiyacını ortaya koymaktadır. Araştırmanın bulguları doğrultusunda, mahalle ölçeğinde mekan odaklı bir perspektifle yaşam kalitesini artırmak üzere politika önerileri geliştirilmiştir.

Anahtar sözcükler: Konut memnuniyeti; genel refah; kentsel yaşanabilirlik; yaşam kalitesi; dönüşüm.
Geliş tarihi: 30.01.2017 Kabul tarihi: 02.11.2017

Online yayımlanma tarihi: 28.12.2017

İletişim: Ezgi Orhan.

e-posta: ezgiorhan@cankaya.edu.tr
TMMOB

Şehir Plancıları Odası 


\section{Introduction}

The concept of quality of life is used to describe the conditions of environment in which people live and their satisfactions with these environments (Pacione, 2003; Myers, 1988). Developed by social scientists to evaluate people well-being, satisfaction and happiness (Fadda and Jiron, 1999), the concept of quality of life refers to the adjustment of conditions of the living environment to the needs, expectations and capacities of people.

The issue of quality of life is central to urban planning as it aims to promote the general welfare, public well-being, and the public interest (Myers, 1988). Decision-makers develop policies to overcome poverty and raise the quality of life at local, urban, regional and national levels. Given that urban planning act as an instrument in reducing the social inequalities, "planners must protect and enhance the quality of life as a strategic source for supporting continued development and for the future satisfaction of citizen" (Myers, 1988; 356). Being a significant means of planners, urban regeneration projects respond the deprivation in urban fabric, economic structure, and social facilities. One of the primary goals of urban regeneration projects is the enhancement of quality of life of local people and making urban areas liveable (Roberts and Sykes, 2000; Bailey, 2004). According to the Roberts and Sykes' exhaustive study (2000), outputs of regeneration with respect to quality of life include housing improvement, education and health gains, and crime reduction. However, in the academic domain, scholars suggest that regeneration efforts address the core issues of providing jobs, public services, housing, quality of life in safe, and physically sound urban areas, policy makers are like to face with a number of problems. One of most concrete problems is to evaluate the success of regeneration objectives. Alberini et al (2003; 193) states that "it is sometimes difficult to compute the monetary benefits of urban regeneration and restoration projects, because many of the services that they provide to the publicincluding aesthetic quality, comfort, sense of neighbourhood identity, town character, preservation of cultural and historical heritage, access to outdoor space-are non-market goods". Measuring the benefits of regeneration projects in terms of quality of life reflects, undoubtedly, the success of the projects. Therefore, assessing the quality of life is worthwhile in a regenerated area to understand the gains in social, economic, environmental and spatial terms.

Previous studies put forward that everyone's quality of life is different (Hazelton, 1985; Zehner, 1977). People may have different viewpoints to problems with respect to their socio-economic basis. A specific event or a physical object may be perceived and appreciated in different ways by different persons. Such a differentiation may be the outcome of the differentiation of social groups relating to their gender, age, disabilities, culture, ethnicity and religion. However, the quality of life, as
Fadda and Jiron (1999; 262) write, "represents more than the private living standards". The evaluation of personal quality of life does not necessarily reflect the community quality of life. That is, individuals' opinion about the community quality of life is different from their opinion of their personal well-being (Myers, 1988). Recognizing the difference between individual and community level quality of life, there is a diverse literature on conceptual and methodological aspects on quality of life.

Within the context of the paper, a comprehensive list of indicators is identified to be applied at the appropriate level for a regenerated neighbourhood. The quality of life indicators were selected to assess outputs of a regenerated area through a case study on Akpınar neighbourhood: a residential area adjoining the city centre. The neighbourhood exemplified a case with a dynamic population due to land redevelopment and departure after a landslide. The selected neighbourhood had the potential to combine physical, social, economic and environmental considerations together. Likewise, the case study contributed to construction of these indicators as a means of quantifying the outputs of area-based regeneration. Rather than presenting a discussion on property-led redevelopment and consequences of economic regeneration, this paper focuses on a comprehensive framework and a case area provided a variety of challenges may affect people's well-being. Methodological frame of this study presents a theory-based choice of indicators which are obtained from a deliberate literature review including economic, ecologic, physical and social aspects of the urban environment. This paper reviews the quality of life indicators and undertakes an empirical research to evaluate the liveability of a neighbourhood respective to the theoretical basis.

\section{Review of the Quality of Life Indicators}

There is a growing concern since the 1970s over the quality of life with the emergence of welfare state (Milbrath and Sahr, 1975; Campbell, et al, 1976; Andrew and Withey: 1976; Zehner, 1977). The quality of modern living was accepted as a simple function of material wealth. "Growing awareness of the importance of the other factors, including the social, political, and environmental health of a nation", Pacione (2003; 19) writes, there is a need to search for indicators, other than those based on gross domestic product, GDP.

The promotion of well-being becomes a central goal for the modern societies. Andrew and Withey $(1976 ; 7)$ write down that "citizen welfare, in broad sense of the word, is the concern not only of national-level governments, but of state, county, city and village governments as well". Since the GDP is the most common measure of the economic activity, it is used widely as a significant indicator for economic performance and living standards at national level. As the scale to quality of life changes from material wealth to social progress, the compo- 
nents of the perceived well-being require to be both objective and subjective to consider the different patterns of appropriation.

Objectively measured welfare indicators such as losing one's job, worsening health conditions, problems related aging, and deterioration of the economic environment may affect the personal well-being and individual life quality. However, even for the economic aspect of life quality, subjective indicators introduce a more solid framework for a household's level of economic safety and resilience or vulnerability in the face of economic risk (Eurostat, 20I5).

Similar to welfare indicators, environmental conditions, measured objectively, may be differentiating from the environmental quality, measured by subjective perceptions. It is significant to employ indicators of environmental conditions in explaining the physical conditions of the living environment. However, having indicators of environmental condition is not enough to understand and evaluate the conditions of the living environment. Fadda and Jiron (1999; 264) argue that "objective indicators cannot measure environmental quality even when they are positive as they do not necessarily entail a good environmental quality". Scholars developed satisfaction models that employ both objective attributes, and perceived or subjective attributes to understand comprehensively (Milbrath, 1978; Marans and Spreckelmeyer, 198I; Weidemann and Anderson, 1985). Thereby, it is claimed that people's perception and appreciation of environmental quality is crucial for urban planners in making decisions about the quality of life.

According to the literature on quality of life, scholars suggest that individuals have different quality of life based on several factors. In line with the previous research and in the context of the study, the indices that are decided upon to explain the life quality include; (I) quality of housing, (2) quality of built environment, (3) quality of pubic space, (4) quality of social environment, (5) quality of natural environment, (6) safety, and (7) quality of services. Supplementing the analysis of previous researches for indicator construction, Table I presents the list of indicators to evaluate the quality of life by focusing on its different aspects.

Housing conditions have a significant influence on the quality of life. Quality of the housing including the structural problems, material deprivation, and lack of amenities would be indicative proxies for lower well-being. The material living condition associates with the housing satisfaction and quality of life. The physical dimension of housing including physical quality, size, functionality, aesthetic aspects and location of housing layout (Onibokun, 1974; Campbell et al, 1976; Galster and Hesser, 1981; Enosh et al., 1984; van Kamp et al., 2003) and social and environmental living conditions (Fried and Gleicher, 196I; Kasarda and Janowtz, 1974; Galster and Hesser, 1981; Kelekci and Berköz, 2006) affects the life quality of residents.

In addition to the housing condition, "the location and surroundings of housing-in other words, the local environmentalso play a vital role" for comfort and satisfaction of people and deficits in local environment may act as a negative influence on the well-being and health of inhabitants (Domanski, et al, 2006; 59). Built environment referring to the physical sphere of an urban environment is accepted as the determinant of quality of life. The aesthetic value and the design of the built environment would affect the life satisfaction of individuals (Alberini et al, 2003; Bonaiuto et al, 2003). The quality of the built environment is as significant as an individual's dwelling since the collective life is to satisfy the human needs.

The community needs on public space affect the quality of life of individuals. Accessibility of the living environment and developed circulation system enhance the convenience of the individuals (Turkoglu, 1997). The spaciousness and the existence of open spaces also improve the quality of life. Functionality and the beauty of the open spaces in addition to the walkability contribute to the quality of a public life (Ewing et al, 2006).

Social environment influence the participation of citizens in the public life. The sense of identity and place attachment may be affected from the pace of life and the collective living environment. Many researchers (Fried and Gleicher, 196I; Kasarda and Janowtz, 1974; Galster and Hesser, 198I; Bonaiuto et al, 2003; Kelekci and Berköz, 2006) prove that social interaction within the neighborhood influences the satisfaction with neighborhood social life. The cultural and economic backgrounds of residents play a role in the formation of the social environment at local level. The voluntarily constructed social connections and the respect to private space enhance the individual life satisfaction in the living environment.

Gaining an important share in the local agenda, environmental issues have a direct impact on the health of individuals and the economic prosperity of societies (Eurostat, 2015). Exposure to the air, water and noise pollution has a very detrimental effect on the well-being of individuals. Being a geographic phenomenon, environmental quality has a significant impact on life satisfaction (Turkoglu, 1997).

Safety refers to "being protected from any situation that puts a person's physical security at risk, such as crime, accidents or natural disasters" (Eurostat, 2015). The perceived risks from natural and physical environment may affect the quality of life of people through posing a physical or emotional threat on life. The feeling of insecure or afraid may act as a significant determinant for the quality of life.

Public services including health, education, and transporta- 
Table I. Indicators of quality of life

\section{Dimensions of life quality Indicators}

Quality of Housing

Housing attributes

\section{Quality of built environment}

Building aesthetics
Building volume
Building density

\section{Quality of public spaces}

Internal Accessibility

External connection

Open spaces

\section{Attributes}

Size of house, size of rooms, size of kitchen, size of balcony, su itability of indoor space, quality of indoor materials, quality of indoor materials, heating, isolation, structural security and rein forcement, landslide risk, calm atmosphere in the apartment, ma intenance of apartment, scenery of housing, day light, value or rental value of housing

Details, shapes and colours of buildings

Space between buildings

Built-up space

Adequacy of space to walk, ease of cycling, designed streets for disabled people, availability of parking lots

Accessibility to city centre, accessibility to other neighbourhoods Availability of open space, accessibility to green areas, maintenan ce of green areas and equipment

\section{Quality of social environment}

Social relations and sense of identity

Integration to neighbourhood's life-style, having friends and rela tives, discreetness of people

\section{Quality of environment}

Environmental health

Maintenance and care

Quality of air, calm environment, clean environment Street lighting, street maintenance and garbage collection, unbuilt or abandoned areas, annoying graffiti or paintings

\section{Safety}

\section{Security and Crime}

Street safety, safety of parks

(Perceived dangerous spaces)

Perceived risks from natural environment Suitability of area for settlement

\section{Quality of services and facilities}

Welfare services
Recreational services
Commercial services
Transportation services
Infrastructural facilities

Good school facilities and day care services, local health service provision, adequacy of religious facilities, security services, acces sibility to public services

Adequacy of sport facilities, venues and entertainment activities, a vailability of cultural attractions

Existence of stores, accessibility to sores frequency of public transport, distribution of bus stops, comfort and crowdedness of buses

Sewer and drainage systems, electricity and water provision

\section{Overall quality of life}

Satisfaction

Quality of life

Expectation
Satisfaction from housing, satisfaction from neighbourhood Quality of life from housing, quality of life from neighbourhood Desire to move from housing, desire to move from neighbourhood 
tion are accepted as important factors in determining how far citizen lives improve. Provision of health and education facilities and a good accessibility to them play a pivotal role in societal well-being. Additionally, the recreational and leisure activities attain to the public quality of life. Sporting, cultural events, entertainments, and voluntarily involved organisation are assumed to directly influence the life satisfaction (Marans and Kweon, 20I I; Turkoglu, I997; Bonaiuto et al, 2003). Similar to welfare and recreational facilities, availability of commercial services and products provide complementary benefit for the life quality.

Overall assessment of individuals on quality of life is accepted as the combination of life satisfaction, eudaimonic well-being and positive feelings (OECD, 20I3; Eurostat, 20I5). The subjective assessment of individuals reflects their quality of life.

Depending on a theoretical framework around the concept of quality of life, this study aims at developing a space sensitive methodological instrument enabling urban planners and local governments to improve the quality of life in urban settlements. Based on the review of literature, the indicators including housing, public spaces, social and natural environment, safety, and services may serve as proxies for explaining the quality of life in a regenerated environment.

\section{Contextual Setting of the Selected Neighbourhood}

Being one of the 124 neighbourhoods of the Cankaya county of Ankara, Akpınar neighbourhood lies nearby one of the main arteries of the city, in opposition to the Middle East Technical University Campus, as illustrated in the Figure I. With a population of 12.114 inhabitants, Akpınar locates in

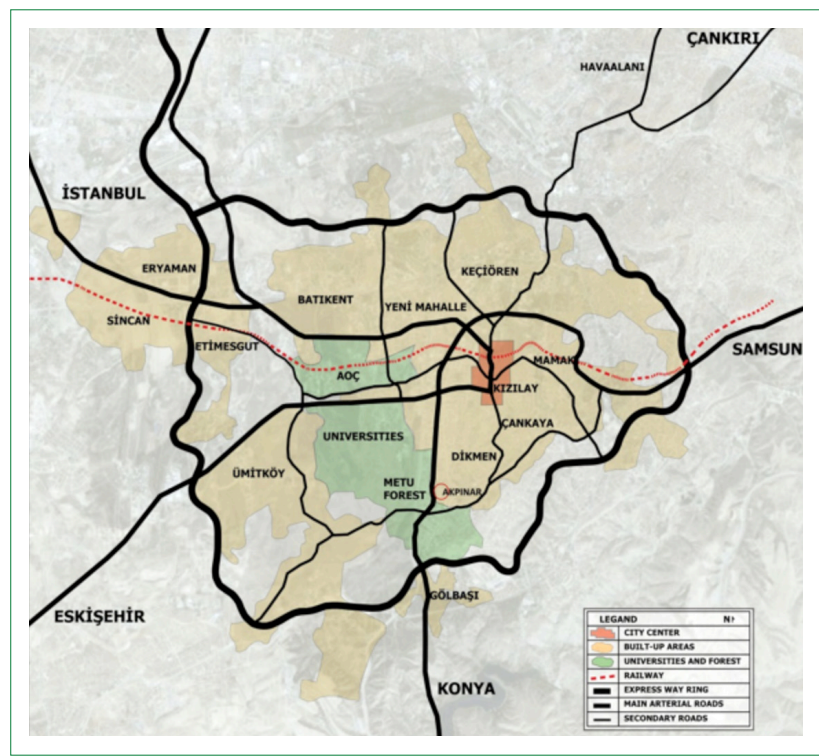

Figure I. Akpınar neighbourhood, Ankara the southern part of the city, $7 \mathrm{~km}$ far away from the central business district. In the earlier times, the neighbourhood was inhabited by low income groups mostly migrated from less developed and rural parts of the country in order to be close to job opportunities that the city provided. The initial cityscape was composed of squatter housing sitting in the slopes of an inconvenient topography. Squatters were used to be single or two-story dwellings built with relatively cheap materials. After the 1990s, the area was transformed by small and medium scale contractors due to its advantageous site close to centre, and the highways and adjacent commercial developments.

With respect to urban transformation process, most of the squatter houses have turned into detached apartments or apartment blocks. As a result of the land speculations in the area, builders obtained the land by contracting the owner of the squatter houses (Haliloğlu Kahraman, 20I3). Therefore, both the house builders and the right-holders, i.e. formerly squatter residents, have become shareholders of apartment buildings, but some of them moved out of the area by renting or selling their houses. New inhabitants of the area belonged to the middle and high income group began to reside in the apartments with moderate construction and material quality.

Apart from the generation efforts, another significant process affecting the spatial formation of the neighbourhood was initiated by a natural disaster. A landslide event hit the neighbourhood damaging a site of 7 apartment blocks. In 2013, the site was declared as risky area by the Ministry of Environment and Urbanism due to the building conditions and geological structure (see Figure 2). Following the decision on unsuitability of the area for settling, the area was appropriately $10.729 \mathrm{~m}^{2}$, refunctioned as green space. 308 inhabitants were evacuated from the risky zone, and a reserved area in the neighbourhood was allocated where the affected households

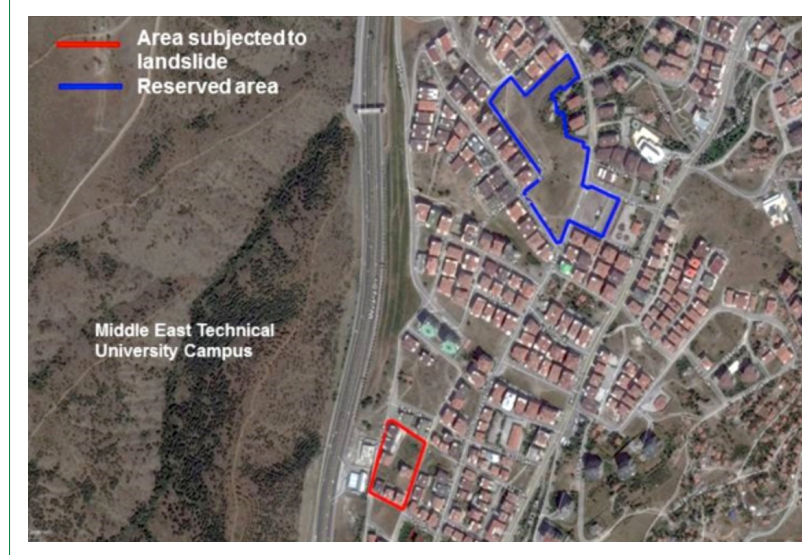

Figure 2. Urban pattern of Akpınar neighbourhood, the risky zone and reserved area 


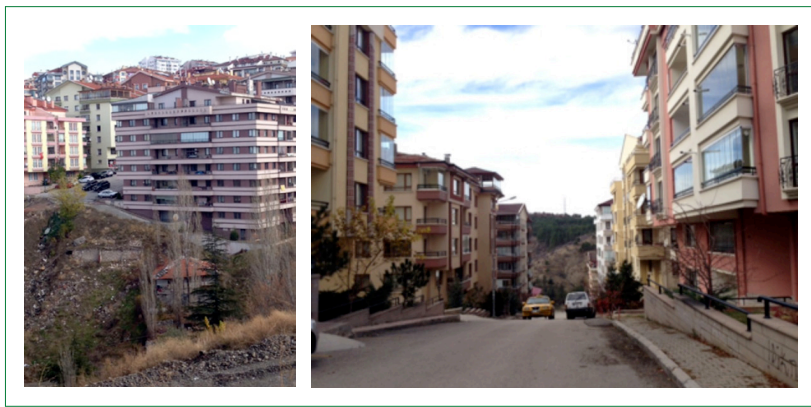

Figure 3. The regenerated built environment

would be given the right to settle in the apartments.

Subjecting to the landslide, the affected households moved to other parts of the city as tenants. During their temporary address changes, the central authority is committed to pay the rents of the affected households. The landslide also influenced the community life in the neighbourhood. Together with the property prices, the demand to reside in the area for newcomers was decreased. In sum, as the urban transformation project changed the spatial organization of the area, the urban lifestyle and consequently the quality of life of people in the neighbourhood have changed in time (see Figure 3). Despite the regeneration efforts, the contextual setting of the selected neighbourhood area provides a variety of factors requiring a detailed analysis to understand the quality of life comprehensively.

\section{Methodology}

This paper proposes a methodology for measuring the quality of life to assist in making public policy. The quality of life concept can be measured subjectively depending on the individual experience as "a long run sense of happiness, satisfaction or well-being" (Milbrath, 1978; 36). The perception of quality of life reflects the lifestyle and cultural preferences of an individual. The quality of living can vary from person to person and may be judged at different levels at different times by the same person. Also, as the quality of life is the collection of numerous elements, it shows a great variety from culture to culture. Despite the diverse literature on urban environmental quality, there is not a uniform and generally accepted conceptual framework "to measure and properly evaluate aspects of, and trends in, environmental quality" (van Kamp, et al, 2003; 6).

In order to develop a measuring instrument on quality of life, indicators and their scaling were operationalized. Firstly, a set of indicators providing that being comprehensive in explaining the quality of life were identified with a detailed reference to previous studies. Then, the subjective perceptions of individuals were scaled on Likert scaling to obtain objective and measurable results. The scales denoting the importance of the given indicator were designed identical for each element. Also, in representation of scales, five equally sized boxes provided the visual impression of equality of intervals. Households were asked to score their perception on each indicator on a five-point scale ranging from "very important" to "not important".

The unit of analysis was determined as neighbourhood. It allows to understand the public and private structures and the relations between people and their environment. Also, the neighbourhood level serves a link between city and home, which provides an intermediate level for conducting a research (Bonaiuto et al, 2003).

Data from the neighbourhood were gathered through the application of questionnaire. The questionnaire include the questions on quality of housing, quality of physical environment, quality of public spaces, quality of social environment, quality of natural environment, quality of services, and safety. The neighbourhood was divided systematically into clusters of 2 to 4 streets. 30 clusters were obtained in order to collect an overall data base from the entire neighbourhood. The universe of the study is equal to the number of the households dwelling in those clusters (approximately 3.040 households). We aimed at conducting 15 questionnaires at average from the each cluster, and finally to reach to 450 households in representing the neighbourhood. The sampling method is random-by-hat-draw. Two site visits were conducted with the participation of 30 pollsters in December 2015. However, some of the selected households remained involuntary in responding the questionnaire so that the response rate was 79.8 per cent which was equal to 359 households.

\section{Limitations}

The quality of life concept includes subjective matters; therefore an analysis on the life quality relies on personal evaluations. Although this research has its roots on self-evaluations of households residing in the neighbourhood, the findings obtained from the study can be generalized. The generalizability of the findings depends on the assumption that every society maintains a general consensus on things that makes people pleased or displeased. The primary limitation of the study is the accuracy of the data, since self-reported information could not be tested or verified. The information collected from the neighbourhood tended to be overstated to draw attention to their pleasure or displeasure about the given indicator of quality of life. Another potential limitation came from the size of the respondents. Randomly selected dwelling units from all streets of the neighbourhood were visited by the pollsters. Unfortunately, some households refused to be a part of the research and did not accept to undertake the 
questionnaire, and some households could not be reached at the time of the survey. Owing to time and financial restrictions, this study could not produce an overall database for the case-study area. Rather, the research had to be limited to the results of the sampling area.

\section{Analytical Procedure on Quality of Life Indicators}

In order to gain a greater insight into the overall picture, it is useful to examine the respondents profile in accordance with their age, gender, education level, occupation, family size, number of employed in the family and home ownership, as shown in Table 2. The sample had 56 per cent female and 44 per cent male respondents, at the age ranging from below 20-year old (3\%), between 21-35 (26\%), between 36-50 (36\%), and between 5I-65 (35\%). The household size of 47 per cent of the sample was between 3 to 4 , and 9 per cent smaller than 3 and 43 per cent was larger than 4 . The highest ratios in the number of employment in the sample were observed in one employee in the house with 47 per cent and two employees with 36 per cent. The economic activity of the respondents was diverse; including housewife, retired, students, private and public sector employees, doorkeepers, and unemployed ones. The education level of the sample was dominated by those with a bachelor degree at $4 \mathrm{I}$ per cent. More than 88 per cent of the respondents lived in their house less than 10 years. 23 per cent of the households in the sample had been living in the same neighbourhood, whereas 68 per cent moved from other neighbourhoods of Ankara, and 9 per cent from other cities. In the sample, while 64 per cent of the respondents was living in the houses that they own, 36 per cent occupied as tenants.

This study examined the quality of life in a regenerated neighbourhood by focusing on the housing and urban environment domains. Firstly, the respondents evaluated their satisfaction levels from housing and urban environment by ranking them from 5 to I. For each attribute in housing and neighbourhood satisfaction, " 5 " indicates the maximum, " 3 " indicates the moderate, "I" indicates the minimum level of satisfaction. Secondly, for examining the overall quality of life in terms of housing, the study used three evaluative variables including "housing satisfaction", "quality of life in the house" and "desire to move from the house". For the exploration of quality of life in terms of urban environment, it similarly used the variables of "neighbourhood satisfaction", "quality of life in the neighbourhood" and "desire to move from the neighbourhood". The sample evaluated their overall satisfaction levels from living in their existing houses and in Akpınar neighbourhood; and their overall housing-related quality of life levels and neighbourhood-related quality of life levels from 5 to I. For each evaluation, "5" indicates the highest and "I"
Table 2. Distribution of the sample according to age, gender, education level, occupation, family size, number of employed in the family, and home ownership

\begin{tabular}{|c|c|c|}
\hline Properties of the sample & $\mathbf{n}$ & $\%$ \\
\hline \multicolumn{3}{|l|}{ Age } \\
\hline$<20$ & 14 & 3.9 \\
\hline $21-35$ & 92 & 25.6 \\
\hline $36-50$ & 129 & 35.9 \\
\hline $51-65$ & 124 & 34.6 \\
\hline \multicolumn{3}{|l|}{ Gender } \\
\hline Female & 202 & 56.2 \\
\hline Male & 157 & 43.8 \\
\hline \multicolumn{3}{|l|}{ Family size } \\
\hline$<3$ & 33 & 9.1 \\
\hline $3-4$ & 170 & 47.4 \\
\hline$>4$ & 156 & 43.5 \\
\hline \multicolumn{3}{|c|}{ Number of employed in the family } \\
\hline 0 & 45 & 12.50 \\
\hline I & 169 & 47 \\
\hline 2 & 129 & 36 \\
\hline$>3$ & 16 & 4.5 \\
\hline \multicolumn{3}{|l|}{ Education level } \\
\hline No education & 12 & 3.3 \\
\hline Primary school graduate & 68 & 19 \\
\hline High school graduate & 119 & 33.1 \\
\hline University graduate & 147 & 41 \\
\hline Postgraduate degree & 13 & 3.6 \\
\hline \multicolumn{3}{|l|}{ Profession } \\
\hline Housewife & 104 & 29 \\
\hline Private sector employee & 80 & 22.2 \\
\hline Public sector employee & 65 & 18.1 \\
\hline Retired & 63 & 17.5 \\
\hline Student & 37 & 10.3 \\
\hline Doorkeeper & 6 & 1.8 \\
\hline Unemployed & 4 & I.I \\
\hline
\end{tabular}

Duration of stay in the existing house

$\begin{array}{lcc}10+ & 41 & 11.4 \\ 5-10 & 168 & 46.8 \\ 5- & 150 & 41.8\end{array}$

Previous place lived

$\begin{array}{lcc}\text { Same neighbourhood } & 84 & 23.4 \\ \text { Other neighbourhood } & 243 & 67.7 \\ \text { Other city } & 32 & 8.9\end{array}$

Home ownership

$\begin{array}{lll}\text { Yes } & 229 & 63.8 \\ \text { No } & 130 & 36.2\end{array}$


indicates the lowest levels. Additionally, the sample evaluates their desire to move from the house and the neighbourhood with "yes" and "no" answers. When the sample stated their willingness to move from the house and/or neighbourhood, this negatively contributed to the quality of life in the house and/or neighbourhood.

To prepare the data for the analysis, the study followed three basic steps. In the first step, the association matrix of levels of satisfaction from each attribute for housing and neighbourhood satisfaction was organized. Then, the association matrices for each level of overall satisfaction from the house and the neighbourhood; each level of overall quality of life in the house and in the neighbourhood; and desire to move from the house and neighbourhood were prepared. Dummy coding was used to determine satisfaction levels for each attribute, the overall satisfaction levels and the overall quality of life for each respondent of the sample. Dummy coding entered categorical (nominal) variables as independent variables in the equation (Hair et al., 1995). The level from 5 to I that the sample indicates for satisfaction and quality of life was coded as "I", while other levels were coded as "0". Similarly, when the sample stated the willingness to move from the house and neighbourhood, the score of this variable was coded as " 0 ", on the contrary, when the sample stated the unwillingness to move from the house and neighbourhood, the score of this variable was coded as "I". With the help of descriptive statistics, Table 3 and 4 respectively shows the ratio of the sample for each satisfaction level of for each attribute in housing satisfaction and neighbourhood satisfaction; and Table 5 and 6 the ratio of the sample for each level of the overall housing and neighbourhood satisfaction. These tables also display the average (mean) level of satisfaction over 5 . Table 7 shows the ratio of the sample which desired and not desired to move from the house and neighbourhood.

As presented in the Table 3, in the total sample, the highest mean value among attributes for housing satisfaction over 5 were the size of the house (4.17), size of the rooms (4.08), peace and calmness in the apartment (4.06), daylighting of the house (4), indoor plan of the house (4), size of the kitchen (3.92), and location (3.83), maintenance of the house (3.79), and size of the balcony (3.76). Particularly, since the household size of the sample is larger than 3, respondents attached their satisfaction with spaciousness attributes. Especially for those staying at house in day time, calmness in apartment associated with higher satisfaction levels. As the neighbourhood has a panoramic forest view, respondent households

Table 3. Frequency of each level of satisfaction and mean of satisfaction scores according to each housing satisfaction attribute

\begin{tabular}{|c|c|c|c|c|c|c|}
\hline \multirow[t]{2}{*}{ Attributes of satisfaction from the house } & \multicolumn{5}{|c|}{ Frequency of Levels of Satisfaction } & \multirow[b]{2}{*}{ Mean } \\
\hline & 5 & 4 & 3 & 2 & $\mathbf{I}$ & \\
\hline Size of the house & 31.8 & 58.2 & 6.9 & 1.7 & 1.4 & 4.1727 \\
\hline Size of rooms & 28.1 & 58.8 & 8 & 3.7 & 1.4 & 4.0864 \\
\hline Peace and calmness in the apartment & 40.4 & 37.3 & 13.1 & 5.9 & 3.3 & 4.0557 \\
\hline Daylighting of the house & 34.8 & 45.1 & 10.0 & 7 & 3.1 & 4 \\
\hline Indoor plan of the house & 28.1 & 52.1 & 12.8 & 5.6 & 1.4 & 4 \\
\hline Size of the kitchen & 33.1 & 44 & 8.6 & 10.4 & 3.9 & 3.9220 \\
\hline Location of the house & 24.5 & 49.9 & 12.2 & 10.6 & 2.8 & 3.8273 \\
\hline Maintenance of the house & 22.3 & 51.5 & 12.5 & 10.9 & 2.8 & 3.7966 \\
\hline Size of the balcony & 31.2 & 40.4 & 8.9 & 11.7 & 7.8 & 3.7549 \\
\hline Scenery of the house & 25.9 & 44.9 & 10.3 & 13.9 & 5 & 3.7270 \\
\hline Sales value or rental value & 21.4 & 42.9 & 24.8 & 5.6 & 5.3 & 3.6964 \\
\hline Heating system & 22.8 & 43.7 & 13.7 & 14.5 & 5.3 & 3.6435 \\
\hline Structural security and reinforcement & 19.8 & 41.2 & 26.7 & 8.1 & 4.2 & 3.6435 \\
\hline Plumbing systems (electricity, gas) & 18.9 & 46.5 & 18.4 & 11.2 & 5.0 & 3.6323 \\
\hline Security of the house against landslide risk & 20.9 & 32.3 & 34.3 & 8.9 & 3.6 & 3.5794 \\
\hline Quality of the indoor materials & 20.3 & 33.2 & 23.4 & 13.4 & 9.7 & 3.4095 \\
\hline Sewage system in the apartment & 15.9 & 46 & 17.3 & 13 & 7.8 & 3.4902 \\
\hline Isolation level & 16.4 & 32.9 & 16.7 & 20.3 & 13.7 & 3.1810 \\
\hline
\end{tabular}


were satisfied with the scenery of their houses (3.73). However, many of the respondents complained about the closeness of the detached buildings to each other. Following the regeneration practises, property values increased and households in the sample were pleased about their houses sales or rental value (3.70). Despite being a newly developed area, the apartment blocks was constructed by small scale building contractors. Therefore, the quality of building materials was low which could be resulted in infrastructural problems in apartments. Respondent households attached lower satisfaction level to material-related attributes than building size, including heating system (3.64), plumbing systems (3.63), sewage system (3.49), isolation (3.18), and indoor material (3.4I) in comparison to the other attributes. With regard to the building safety against natural disaster risks, there were not any specially designed measures. Particularly, the area was subjected to landslide, so that it was expected a decrease in the housing satisfaction level of respondents. Households in the sample were satisfied with structural security and reinforcement (3.64), and security of the house against landslide risk (3.58) which were below their satisfaction level associated with the spaciousness of their housing.

Respondent households in Akpınar Neighbourhood generally satisfied with quality of built environment. Following the urban regeneration process, the built environment was dramatically changed. Although respondents were satisfied with the building aesthetics (3.8), they did not equally attach to the building volume (3.39) and density (3.16). Particularly, in the area closure of detached buildings to each other and to street contributed to the high density development which made respondents unsatisfied with the building density.

To understand the quality of public space in the case area, questions about internal accessibility, external connection, and open spaces of the neighbourhood were asked. Respondents attached lower satisfaction to internal accessibility in the neighbourhood compared to external connection. Respondent households were satisfied about the wideness of streets (3.23) and adequacy of parking lots (3.28), yet they found streets for pedestrians (2.55) and for disabled people (1.92) inappropriate. Their complaints behind unsuitability of streets for walking especially disabled ones associated with the slopes and inadequate maintenance of streets and pavements. On the other hand, they were satisfied with the connection to city centre (3.76) and other parts of the city (3.54) due to the close location of the neighbourhood to centre and the frequently serving para-transit modes to centre allowing to access other parts of the city. Respondent households are not pleased from the adequateness of green spaces (2.38), their accessibility (2.45) and maintenance (2.45). Among the respondents, especially those being retired or housewives were complaining about the green areas since they demand open space functions at most for their leisure activities. Apart from the lack of the green space of the neighbourhood, maintenance of the green spaces was neglected by municipality. Additionally, respondent found those areas unsecure and complained about the stray dogs around the areas where especially people with children did not prefer to use those areas.

Before the regeneration project, people residing in the neighbourhood were used to know each other and their social relations were quite strong. Subject to such a transformation and arrival of newcomers, social relations were expected to reflect a new way of living. Yet, respondents were pleased with the quality of social environment in terms of social relations (3.58), despite they had less friends or relatives close to the neighbourhood (3.15). Respondent households had a high level of education which was expected to associate with the high tolerance and tranquillity among people, so that they were satisfied with the discreetness of inhabitants (3.79). Respondents also felt a strong sense of belonging to the neighbourhood (3.58).

Most of the respondent households living in the Akpınar neighbourhood were satisfied with the quality of environment. Locating opposite to the forestry, the neighbourhood benefitted from the quality of air (4.03). Also, respondents attached peace and calmness of the neighbourhood (3.95) and the cleanness of streets (3.63) to the quality of environment. Additionally, respondent households were almost satisfied with the maintenance and care of the environment; and did not bother much from the abandoned areas (3.69) or graffiti or paintings on walls (3.67), in common. Female respondents complained about the existence of unbuilt areas that were used by unfamiliar teenagers and strangers resulting in a decrease in their quality of life in terms of insecurity. However, the maintenance and clearance of roads (2.89) was seen as a problem for respondents because of the topographical structure of the area especially in rainy days and winter times. Bad quality of roads including the pathways was caused by slope and shape of pavement, according to the respondents. When it was raining, streets were polluted by land, and respondents complained about the inadequacy of the precautions.

Respondents were more or less satisfied with the security of streets (3.4). In common, they did not feel themselves insecure in going around late in the evening (3.46). However, female respondents complained that they could not walk comfortable in evenings despite a general satisfaction level of street lighting. The satisfaction level of respondents from the security of parks (3.36) was lower than of streets. Respondents mentioned that they did not prefer to go to the parks with their children as they found those parks insecure. With respect to the perceived risks from natural environment, re- 
Table 4. Frequency of each level of satisfaction and mean of satisfaction scores according to each neighbourhood satisfaction attribute

\begin{tabular}{|c|c|c|c|c|c|c|}
\hline \multirow{2}{*}{$\begin{array}{l}\text { Attributes of satisfaction } \\
\text { from the neighbourhood }\end{array}$} & \multicolumn{5}{|c|}{ Frequency of levels of satisfaction } & \multirow[b]{2}{*}{ Mean } \\
\hline & 5 & 4 & 3 & 2 & $\mathbf{I}$ & \\
\hline Quality of air & 35.7 & 44.8 & 9.5 & 6.4 & 3.6 & 4.0250 \\
\hline peace and calmness in the neighbourhood & 33.1 & 46 & 9.2 & 6.4 & 5.3 & 3.9526 \\
\hline Building aesthetics & 24 & 44.8 & 19.5 & 8.9 & 2.8 & 3.8 \\
\hline Accessibility from neighbourhood to city centre & 24.8 & 46.7 & 12.3 & 12 & 4.2 & 3.7604 \\
\hline Discreetness of inhabitants & 28.5 & 43.7 & 12.8 & 8.6 & 6.4 & 3.7911 \\
\hline Proximity to religious facilities & 22.3 & 51.2 & 12.3 & 7.2 & 7 & 3.7465 \\
\hline Adequacy of religious facilities & 20.6 & 52.4 & 12 & 8.3 & 6.7 & 3.7187 \\
\hline Existence of vacant or unbuilt areas & 12.3 & 33.1 & 21.4 & 20.1 & 13.1 & 3.6908 \\
\hline Existence of graffiti and paintings & 15.6 & 32.6 & 22.6 & 17 & 12.2 & 3.6713 \\
\hline Street lighting & 24 & 42.6 & 13.9 & 15.3 & 4.2 & 3.6685 \\
\hline Cleanness of the street & 21.2 & 44.8 & 15.9 & 12.3 & 5.8 & 3.6323 \\
\hline Social relations in the neighbourhood & 21.7 & 44.6 & 13.9 & 9.2 & 10.6 & 3.5766 \\
\hline Sense of belonging to the neighbourhood & 22.6 & 42.6 & 14.5 & 10.6 & 9.7 & 3.5766 \\
\hline Accessibility to other parts of the city & 20.3 & 42.9 & 15 & 14.8 & 7 & 3.5487 \\
\hline Quality of electricity and water services & 13.1 & 51.3 & 17 & 13.9 & 4.7 & 3.5404 \\
\hline Security of streets on evenings & 12.8 & 28.1 & 20.6 & 22.6 & 15.9 & 3.4596 \\
\hline Adequacy of public transportation stops & 20.9 & 38.2 & 17.8 & 14.5 & 8.6 & 3.4819 \\
\hline Security of the street & 12.8 & 24 & 22 & 25.3 & 15.9 & 3.4039 \\
\hline Building volume & 16.7 & 40.9 & 14.2 & 20.1 & 8.1 & 3.3816 \\
\hline Security of parks & 8.6 & 21.2 & 22 & 27.6 & 20.6 & 3.3565 \\
\hline Adequacy of preschool facilities & 13.9 & 37 & 24.2 & 14.8 & 10.1 & 3.3008 \\
\hline Adequateness of parking lots & 15.0 & 37.3 & 18.1 & 18.4 & 11.2 & 3.2674 \\
\hline Wideness of streets & 16.4 & 34.3 & 16.1 & 22.6 & 10.6 & 3.2340 \\
\hline Building density & 14.5 & 31.2 & 21.2 & 22.6 & 10.5 & 3.1643 \\
\hline Frequency of public transportation & 24.5 & 35.1 & 17.8 & 13.4 & 9.2 & 3.1588 \\
\hline Proximity to relatives and friends & 14.2 & 32.6 & 20.6 & 19.5 & 13.1 & 3.1532 \\
\hline Proximity of health services & 13.9 & 33.8 & 18.9 & 19.5 & 13.9 & 3.1421 \\
\hline Comfort and quality of buses & 16.1 & 27.3 & 21.2 & 23.7 & 11.7 & 3.1253 \\
\hline Precautions for landslide risk & II.I & 23.4 & 41.2 & 14.2 & 10.1 & 3.1142 \\
\hline Adequacy of health services & 12.2 & 34.5 & 18.1 & 20.1 & 15.1 & 3.0891 \\
\hline Varieties in public transportation facilities & 21.4 & 34.8 & 17.5 & 18.1 & 8.2 & 3.0752 \\
\hline Proximity to educational facilities & 9.7 & 30.4 & 26.7 & 19.8 & 13.4 & 3.0334 \\
\hline Adequacy of sewage and drainage systems & 6.7 & 34 & 27 & 18.9 & 13.4 & 3.0167 \\
\hline Proximity to commercial facilities & 19.8 & 33.1 & 13.6 & 19.8 & 13.7 & 2.9749 \\
\hline Proximity to security services & 6.4 & 27.9 & 27.9 & 23.9 & 13.9 & 2.8886 \\
\hline Quality and maintenance of roads & 12 & 21.4 & 23.1 & 29.7 & 13.8 & 2.8858 \\
\hline Existence of qualified education services & 8.4 & 22.8 & 30.4 & 23.1 & 15.3 & 2.8579 \\
\hline Appropriateness of streets for pedestrians & 9.5 & 18 & 12.3 & 38.2 & 22 & 2.5487 \\
\hline Proximity to cultural facilities & 4.4 & 17 & 23.1 & 30.3 & 25.2 & 2.4568 \\
\hline Accessibility to green areas & 8.9 & 17.5 & 12.9 & 30.9 & 29.8 & 2.4485 \\
\hline Quality and maintenance of green areas & 8.6 & 15.9 & 15.3 & 32.1 & 28.1 & 2.4485 \\
\hline Adequateness of green areas & 7.2 & 14.8 & 15.3 & 34 & 28.7 & 2.3788 \\
\hline Adequacy of commercial facilities & 17 & 28.4 & 15.3 & 20.9 & 18.4 & 2.1838 \\
\hline Adequacy of cultural facilities & 3.9 & 13.1 & 23.1 & 32.3 & 27.6 & 1.9304 \\
\hline Appropriateness of streets for disabled people & 3.9 & 8.1 & 10 & 32.3 & 45.7 & 1.9220 \\
\hline Adequacy of sport facilities & 3.6 & 10.6 & 20.6 & 34.5 & 30.7 & 1.8914 \\
\hline
\end{tabular}


spondents were less satisfied with the precautions for the landslide risk (3.II). They found the soil condition unsuitable for built environment and the geographical conditions in the area unsafe to live in. However, according to sample results, people were likely to ignore the landslide risk despite the recent experienced event in the area.

The quality of public services and facilities in this study were categorized as welfare services, recreational services, transportation services and infrastructural facilities. To begin with, households in the sample attached lower satisfaction with educational facilities (2.86) than day-care centres, (3.30) and local health services (3.03). Despite the existence of five schools serving at different stages of education, respondents were not satisfied with the quality of public school facilities in the neighbourhood. Respondents were more satisfied with the accessibility of schools (3.03) and health services (3.09) than of security services (2.89). Among other services, adequacy of religious facilities (3.7I) and accessibility to them (3.75) associated with the highest satisfaction level of respondents. With regards to the recreational services, households in the sample attached least satisfaction levels to adequacy of cultural facilities (1.93) and sports facilities (1.89). Despite the regeneration of the whole area, the efforts were mostly on the transformation of squatter houses into apartments. The neglect of the social and recreational facilities in the regeneration policies were observed in the satisfaction level of households on cultural events, entertainment activities and sport grounds. Together with the inadequacy of cultural attractions such as cinema, library, theatre, and indoor and outdoor sport facilities, households had to meet their recreational demands out of the neighbourhood so they were unsatisfied with the proximity of cultural facilities (2.46). Also, satisfaction levels of

Table 5. Frequency of evaluations of housing and neighbourhood satisfaction (over 5, \%)

\begin{tabular}{lcccccc}
\hline Satısfaction & \multicolumn{4}{c}{ Levels of Satisfaction (\%) } & Mean \\
\cline { 2 - 6 } & $\mathbf{5}$ & $\mathbf{4}$ & $\mathbf{3}$ & $\mathbf{2}$ & $\mathbf{I}$ & Value \\
\hline From the house & 26.7 & 63.5 & 5.3 & 3.4 & I.I & 4.1142 \\
From the & 18.1 & 56.8 & 15 & 7.5 & 2.6 & 3.8050 \\
neighbourhood & & & & & & \\
\hline
\end{tabular}

Table 6. Frequency of evaluations of housing-related and neighbourhood-related quality of life (over 5, \%)

\begin{tabular}{lcccccc}
\hline \multirow{2}{*}{ Qualıty of lıfe } & \multicolumn{4}{c}{ Levels of quality of life (\%) } & \multirow{2}{*}{ Mean } \\
\cline { 2 - 6 } & $\mathbf{5}$ & $\mathbf{4}$ & $\mathbf{3}$ & $\mathbf{2}$ & $\mathbf{I}$ & Value \\
\hline Housing-Related & 21.7 & 63 & 10.6 & 3.3 & 1.4 & 4.0028 \\
\hline Neighbourhood-Related & 14.8 & 56 & 18.9 & 6.4 & 3.9 & 3.7131 \\
\hline
\end{tabular}

the households were below the average for the commercial facilities; they found the number of stores and the diversity of their products inadequate in the neighbourhood and attached low level satisfaction for the adequacy of commercial facilities (2.18), and the proximity to stores (2.98). Finally, with respect to the quality of transportation services, it was found that households in the sample were satisfied with the frequency of public transportation (3.16), varieties of public transportation modes (3.08), distribution of bus stops (3.48) and the comfort and crowdedness of the buses (3.13). Additionally, respondent households were pleased with infrastructural facilities in the neighbourhood. They were more satisfied with the electricity and water provision (3.54) than the sewer and drainage system (3.02). Due to the topographical structure, households complained about the inadequacy of drainage system which may lead to flood in case of excessive rain.

After examining the factors affecting quality of life, the satisfaction levels of households from their houses and neighbourhood was analysed. It was found out that households attached higher satisfaction level with their houses (4.II) than their neighbourhoods (3.8I), as shown in the Table 5. Similar findings were observed in the assessment of households on quality of life. Respondents associated higher quality of life values with their houses (4.00) than their neighbourhoods (3.7I), as presented in the Table 6. Parallel to the findings, Table 7 showed that 66 per cent of the total sample mentioned their unwillingness to move from their existing houses or Akpınar neighbourhood.

Since there is not a regular basis for households to identify how people evaluate their quality of life, it is required to define a set

Table 7. Frequency of desire to move from the house and the neighbourhood

\begin{tabular}{lccc}
\hline Not desıre to move & n & $\%$ & Mean value \\
\hline From the existing house & 237 & 66.0 & 0.6602 \\
From Akpınar neighbourhood & 237 & 66.0 & 0.6602 \\
\hline
\end{tabular}

Table 8. Comparison of the overall housing-related and neighbourhood-related quality of life value in Akpınar Neighbourhood with maximum value

Overall qualıty of Iıfe Value in the area* Maximum value***

\begin{tabular}{lll}
\hline Housing-Related & 8.7772 & II \\
Neighbourhood-Related & 8.1783 & I I \\
\hline *Overall value of quality of life in the area (per household)=Mean value of satis- \\
faction level+Mean value of quality of life level+Mean value of not desire to move \\
**Overall maximum value of quality of life (per household)=Maximum satisfaction \\
level+Maximum quality of life level+Value of not desire to move
\end{tabular}


Table 9. Frequency of attributes of expectations to Improve quality of life

\begin{tabular}{|c|c|c|}
\hline Attributes of expectations for quality of life & $\mathbf{n}$ & $\%$ \\
\hline More green areas in the neighbourhood & 270 & 75.2 \\
\hline More walkable streets & 249 & 69.3 \\
\hline More walking paths & 231 & 64.3 \\
\hline More secure playgrounds for children & 224 & 62.4 \\
\hline More sport facilities & 216 & 60.2 \\
\hline To have facilities to spend my leisure time & 198 & 55.2 \\
\hline More secure street & 198 & 55.2 \\
\hline Increase in the number of health services & 167 & 46.5 \\
\hline Improvement in the infrastructure & 166 & 46.2 \\
\hline To make isolation in the apartment & 161 & 44.8 \\
\hline To have bigger balcony/garden & 160 & 44.6 \\
\hline To live in a structurally more secure house & 156 & 43.4 \\
\hline Increase in the number of educational facilities & 155 & 43.2 \\
\hline More lightened street & 155 & 43.2 \\
\hline Improvement in public transportation facilities & 153 & 42.6 \\
\hline To have indoor materials in good quality & $|5|$ & 42.1 \\
\hline To have more daylighting in the house & 149 & 41.5 \\
\hline To have good scenery & 148 & 41.2 \\
\hline Increase in the commercial facilities & 145 & 40.4 \\
\hline To have bigger kitchen & 140 & 39 \\
\hline Reinforcement in the apartment against land sliding & 136 & 37.9 \\
\hline More aesthetic buildings & 134 & 37.3 \\
\hline To live in a clean apartment & 131 & 36.5 \\
\hline Improvement in public transportation network & 128 & 35.6 \\
\hline Increase in the capacity of parking lots & 126 & 35.1 \\
\hline More peace and security in the street & 121 & 33.7 \\
\hline To live in a bigger house & 120 & 33.4 \\
\hline Good social relations in the neighbourhood & 115 & 32 \\
\hline To have more functional plan & 113 & 31.5 \\
\hline An increase in the value of the house & 113 & 31.5 \\
\hline To renovate my house & 107 & 29.8 \\
\hline To have more than one bathroom & 103 & 28.7 \\
\hline Improvement in the sense of belonging towards the neighbourhood & 81 & 22.5 \\
\hline More clean neighbourhood & 159 & 22.2 \\
\hline Increase in the number of religious facilities & 77 & 21.4 \\
\hline A decrease in the rent & 69 & 19.2 \\
\hline Less floors in the apartment & 56 & 15.6 \\
\hline To move to another house & 55 & 15.3 \\
\hline To move to another neighbourhood & 55 & 15.3 \\
\hline Less people living in the apartment & 35 & 9.7 \\
\hline
\end{tabular}


of questions for overall quality of life. The set of questions are to evaluate the overall quality of life by asking the households' satisfaction level, the quality of life for their housing and neighbourhood, and their expectation to relocate from their housing and neighbourhood. The indicators of satisfaction level and the quality of life are measured on five-point scale, and the willingness to relocate was measured dichotomously where ' 0 ' indicates the desire to move and 'l' to live in the area. The overall quality of life defined in the study is an index of three variables that ranges from 2 to $\mathrm{II}$. In this range, II indicates the most preferable living quality while 2 indicates the least. The mean score on housing-related quality of life was 8.78 , and the mean score on neighbourhood-related quality of life was determined as 8,18 . Table 8 shows the comparison of the overall housing-related and neighbourhood-related quality of life value in Akpınar Neighbourhood with maximum value.

The last query was about the expectations of the respondents for their quality of life. The attributes for a better quality of life was summarized in the Table 9. The most frequently mentioned attributes were about the quality of public spaces and open spaces. In parallel to the findings on dissatisfaction of respondents due to inadequacy of open spaces, the most frequently mentioned attributes for a better quality of life were having more green areas (75.2\%), more walkable streets (69.3\%), more walking paths (64.3\%), more secure playgrounds for children (62.4\%), more sport facilities (60.2), and more facility and attractions to spend leisure time (55.2\%). The following two attributes, including increase in number of local health services (46.5\%), improvements in the lifeline systems (46.2) pointed that an improvement in the public services would contribute to the quality of life. Moreover, it was found that respondent households were satisfied with their housing so that attributes related to housing were less frequently mentioned. Similarly, the attributes that were associated with higher satisfaction level in present life did not mentioned frequently. For the least frequently mentioned attributes, since the apartment blocks were newly produced, households would not be attached to an increase in the value of their houses (31.5\%), a renovation in their houses (29.8\%), having more than one bathroom (28.7\%), a decrease in housing rent (19.2\%). Also, the attributes of improvement in the sense of belonging towards the neighbourhood (22.5\%), less floors in apartment (15.6\%) and less people living in the apartment (9.7\%) were not associated with the expectations of households for a better quality of life. The reason may relate with the working life and an apartment type life-style that limited the social connections, so that alienation from the neighbours decreased the importance of attributes related to social life. Also, as the overall quality of life from house and neighbourhood was good, the attributes related to moving to another house $(15.3 \%)$ and to another neighbourhood (15.3\%) were not associated with a better quality of life.

\section{Conclusion}

Policy-makers and urban planners are to improve the quality of life and environment of a community. They should be aware the main distinction between environmental conditions and environmental quality. While the former provides physical facts and objective knowledge about the environment, the latter is necessarily a subjective explanation of environment by individuals showing their pleasure or displeasure experiences. A research on quality of life based on the subjective statements, such as those set forth in this paper, provides significant tools for decision-makers in understanding the needs and expectations of the community.

Quality is a context-dependent concept by definition. City planners and policy makers are to make emphasis on the environmental quality and well-being for their interventions such as regeneration. However, social benefits cannot be fully defined by science, so that it is recommended to gain an insight in the aspects of quality of life. Observing the development process of Akpınar neighbourhood, we claimed that households assess their quality of life on individual basis that is often overlooked in both public policies and urban planning decisions.

The review on urban development puts forward that the Akpınar neighbourhood was formed by squatter houses settled on slopes of the south Ankara. Income inequalities and social incapability consolidated in the squatter neighbourhoods leading to spatial segregation, as observed in Akpınar neighbourhood. Under the neoliberal economic conditions, the inequalities and socio-spatial segregation become concrete in the urban, especially residential environment. In order to achieve social coherence and obtain economic gain, the introduction of regeneration process in the 1990s shifted the squatter structure of the neighbourhood into regularly constructed apartment buildings. The regeneration process was resulted in population increase and high density development on a hazard-prone area. In 2003, a landslide hit the neighbourhood severely, and approximately 300 households were evacuated from the area. Despite the investments made for a better living environment, the regeneration process could not respond the problems originating from the hazard prone characteristics of the area. Beside to a decrease in demand from newcomers, residents preferred to live in the neighbourhood even after the landslide event. In this respect, it was worthwhile to ask households how they evaluate their quality of life regarding their houses and neighbourhood.

The methodology used in this research to explain the quality of life in a neighbourhood produces rationally credible and reliable results. Firstly, households were satisfied with their quality of life regarding their houses and neighbourhood. De- 
spite the difficulties of the topographical structure, respondent households did not prefer to move from their living environments. This tendency might be controversial at the first sight regarding the hazard prone structure of the area, and the difficulties in their daily life due to the natural conditions. The reason may associate with the close location of the neighbourhood to the central district of the city which enhance the quality of life with respect to the quality of welfare services, transportation and infrastructural services, safety and quality of environment and its maintenance. Also the high satisfaction levels may accompany with the newly constructed built environment in which almost all housing attributes satisfy the residents. It was revealed that respondents appreciated their quality of life through the neighbourhood level quality of life indicators regardless of the natural and topographical conditions. Additionally, divergence from the previously constructed life habits seemed to have limited influence on the social relations and place attachment. Respondent households were satisfied from their housing attributes, the quality of built environment, and the social environment. Although the former built environment provided a highly connected social milieu, residents of the new regular built environment were still satisfied with the social relations in neighbourhood. The major indicator that makes residents unsatisfactory associated with the quality and quantity of open spaces and thus recreational services. This area was not developed in accordance with the commercial, recreational and cultural amenities which reduce the quality of life in the area. While the residents benefited from the closeness of the neighbourhood to central district, the proximity reduced the formation of adequate entertainment activities and shopping facilities. Since the central district provided a great variety of cultural and commercial services, the neighbourhood could not attract such services which affected negatively the satisfaction level of residents. Thus, it is worthwhile to note that in development of an area, public facilities and spaces are important in the quality of life and should be designed in accordance with the necessities of the residents.

The debate taking place in this inquiry can be supported by further research. First, it may seem that the national-level socio-economic figures may portray a good quality of life for a district. However, this study showed that residents' appreciation on their quality of life changes according to the personal evaluation. Therefore, it is required to analyse localities and subjective evaluations to understand the perceived quality of life. These findings should be considered as input for the planning process and as a performance criteria in determining the plan success. In policy development, city government should not only consider the need for the regeneration of squatter neighbourhoods, but also improve social, recreational, educational and infrastructural services. Second, in line with the indicators presented in this study, it is necessary to widen the research approach to recognize the variations in quality of life among neighbourhoods with socio-demographic differences. Parallel studies in other neighbourhoods or cities present opportunities for comparative analysis in document the quality of life and monitor a place-sensitive experience. 


\section{REFERENCES}

Alberini, P., Riganti, P., \& Longo, A. (2003). Can people value the aesthetic and use services of urban sites? Evidence from a survey of Belfast residents. Journal of Cultural Economics, 27(3-4), 193-213. DOI: 10.1023/A:1026317209968.

Andrew, F.M. and S.B. Withey (1976). Social Indicators of Well Being: America's Perception of Life Quality, Plenum Press, New York.

Bonaiuto, M., Fornara, F., \& Bonnes, M. (2003). Indexes of perceived residential environment quality and neighbourhood attachment in urban environments: a confirmation study on the city of Rome. Landscape and urban planning, 65(1), 41-52.

Campbell, A., Converse, P., \& Rodgers, W.(1976). The quality of American life: Perceptions, Evaluations and Satisfactions. New York: Russell Sage Foundation.

Domanski, H., Ostrowska, A., Przybysz, D., Romaniuk, A., Krieger, H., (2006). First European Quality of Life Survey 2003, European Foundation for the improvement of living and working conditions, Dublin, ISBN 92-897-0935-9.

Enosh, N., Leslau, A., Shacham, J. (1984). Residential quality assessment: a conceptual model and empirical test, Social Indicators Research (14) 453-76.

Eurostat, web page (2015). Quality of life indicators - economic and physical safety, http://ec.europa.eu/eurostat/statistics-explained/index.php/ Quality_of_life_indicators_-_economic_and_physical_safety, last accessed on December 2015.

Ewing, R., Handy, S., Brownson, R. C., Clemente, O., \& Winston, E. (2006). Identifying and measuring urban design qualities related to walkability. Journal of Physical Activity \& Health, 3 (1): 223-240.

Fadda, G. and Jirón, P. (1999). Quality of life and gender: a methodology for urban research, Environment and Urbanization, 11(2): 261-270.

Flores, A., Pickett, S.T.A, Zipperer, W.C., Pouyat, R.V., Pirani, R. (2000). Adopting a modern ecological view of the metropolitan landscape: the case of greenscape system for the New York region. Landscape and urban planning, 39, 295-308.

Fried, M., Gleicher, P. (1961). Some sources of residential satisfaction in an urban slum, Journal of the American Institute of Planners (19) 539-68.

Galster, G.C., Hesser, G.W. (1981) Residential satisfaction compositional and contextual correlates, Environment and Behavior (13) 735-58.

Hair, J. F., Anderson, R. E., Tatham, R. L., Black, W. C. (1995). Multivariate data analysis with readings, Prince-Hall Inc, Fourth Edition, New Jersey.

Haliloğlu Kahraman, Z. E. (2013). Dimensions of housing satisfaction: a case study based on perceptions of rural migrants living in Dikmen, METU Journal of Faculty of Architecture, 30(1): 1-27. DOI: 10.4305/METU. JFA.2013.1.1

Hazelton, J. (1985). Quality of Life Indicators for Austin. Report by the Quality of Life Advisory Committee to the Quality of Life Division, Austin Chamber of Commerce.

Hemphill, L., Berry, J., and McGreal, S. (2004). An Indicator-based Approach to Measuring Sustainable Urban Regeneration Performance: Part 1, Conceptual Foundations and Methodological Framework, Urban Studies, (41:4) 725-755.

Kasarda, J.D., Janowitz, M. (1974). Community attachment in mass society. American Sociological Review (39) 328-39.

Kelekçi, Ö. L., Berköz, L. (2006) Mass housing: User satisfaction in housing and its environment in İstanbul, Turkey, European Journal of Housing Policy (6: 1) 77-99.

Marans, R.W. (2003), Understanding Environmental Quality Through Quality of Life Studies: The 2001 DAS and its use of Subjective and Objective Indicators, Landscape and Urban Planning , 65: 73-83.

Marans, R.W., Spreckelmeyer, K.F. (1981), Evaluating Built Environments: A Behavioral Approach. University of Michigan, Institute for Social Research and the Architectural Research Laboratory, Ann Arbor.

Marans, R.W., Kweon, B-S, (2011) The Quality of life in Metro Detroit at the beginning of the Millennium, in Marans, R.W. and Stimson, R.J. (eds) Investigating quality of urban life: Theory, methods, and empirical research, Social Indicators Research Series, vol.45, Springer, New York.

Milbrath, L., and Sahr, R. (1975). Perceptions of environmental quality. Social Indicators Research, 1, 397-438.

Milbrath, L.W. (1978). Indicators of environmental quality, UNESCO Reports and papers in the social sciences no.38, pp.32-56.Place de Fontenoy, 75700 Paris, France, ISBN 92-3-011 539-7.

Myers, D. (1988). Building Knowledge about Quality of Life for Urban Planning, Journal of the American Planning Association, 54:3, 347-358, DOİ: $10.1080 / 01944368808976495$.

Newman, P.W.G. (1999). Sustainability and cities: extending metabolism model. Landscape and Urban Planning, 33, 219-226.

OECD (2013). OECD Guidelines on measuring subjective well-being, OECD Publishing, DOI:10.1787/9789264191655-en

Onibokun, A. (1974). Evaluating consumers' satisfaction with housing. Journal of the American Institute of Planners (40) 189-200.

Pacione, M. (2003). Urban environmental quality and human wellbeing-a social geographical perspective, Landscape and Urban Planning, 65: 19-30.

Roberts, P., and Sykes, H. (2000). Urban regeneration: A Handbook, London, Thousand Oaks, New Delhi: SAGE Publications.

State Planning Organization-SPO, (1996). Socio-economic development index survey of counties in Turkey, State Planning Organization Press: Ankara.

State Planning Organization- SPO, (2004) Socio-economic development index survey of counties in Turkey, State Planning Organization Press: Ankara.

Türkoğlu, H. (1997). Residents' satisfaction of housing environments: the case of İstanbul, Turkey, Landscape and Urban Planning (39) 55-67.

Van Kamp, I., Leidelmeijer, K., Marsman, G., \& De Hollander, A. (2003). Urban environmental quality and human well-being: Towards a conceptual framework and demarcation of concepts; a literature study. Landscape and urban planning, 65(1), 5-18.

Weidemann, S., Anderson, J.R. (1985). A conceptual framework for residential satisfaction. in: Altman, I., Werner, C.H. (Eds.), Home Environments. Plenum, New York.

Zehner, R. (1977). Indicators of the quality of life in new communities. Cambridge: Ballinger. 